Donatelli, C., et al., 2020, A nonlinear relationship between marsh size and sediment trapping capacity compromises salt marshes' stability: Geology, v. 48, https://doi.org/10.1130/G47131.1

\title{
A non-linear relationship between marsh size and sediment trapping capacity compromises salt marshes' stability
}

Carmine Donatelli (*), Xiaohe Zhang (*), Neil K. Ganju, Alfredo L. Aretxabaleta, Sergio Fagherazzi $^{1}$, Nicoletta Leonardi ${ }^{1}$

The systems analysed in this manuscript have been the object of several studies carried out by the United States Geological Survey (USGS) and by the Long Term Ecological Research Network (LTER) over the last few years. Several investigations have used COAWST and Delft3D as numerical tools in these systems. The numerical models used in this work had been extensively calibrated and tested in such studies (Table S1). Herein, we adopted a cumulative research approach which builds on existing methodologies and tools to develop a new and generalized understanding on the global response of bay systems to marsh loss. For our ensemble modelling approach, we decided to add bays using models already used in those systems, leveraging on the effort of several researchers in the past years. Our goal is to add more bays in the near future by inviting more researchers to collaborate within this framework. Table S1 lists the studies which have first dealt with the calibration of some of the investigated systems and the associated modelling frameworks.

\section{Methods}

The hydrodynamics and sediment transport of the bays were simulated using the COAWST (Coupled-Ocean-Atmosphere-Wave-Sediment Transport Modeling System) modeling framework [Warner et al., 2010] for Great South Bay, Jamaica Bay, Barnegat Bay-Little Egg Harbor and Chincoteague Bay (Table 1). The ocean model used in COAWST is ROMS (Regional Ocean Modeling System), which incorporates a sediment transport module based on the Community Sediment Transport Modeling System [Shchepetkin and McWilliams, 2005; Warner et al., 2008]. The computational fluid dynamics package Delft3D [Lesser et al., 2004] was used for Plum Island Sound and Virginia Coast Reserve (Table 1). Numerical simulations were conducted to identify the impact of different marsh removal scenarios on tidal propagation and on the amount of sediments potentially being retained in the system given an initial sediment input. The suspended sediment transport was modelled by solving the advectiondiffusion equation, and by accounting for source/sink terms induced by downward settling or upward flux of eroded material. The depositional flux is proportional to the bottom concentration and settling velocity values; the erosion flux was calculated following Ariathurai and Arulanandan formulation [1978] in ROMS and Partheniades formulation [1965] in Delft3D. In both formulations the erosion flux depends on the exceedance shear stress with respect to the critical shear stress, and on a user-defined erosion parameter. The selected turbulence model was the $\mathrm{k}-\varepsilon$ scheme [Rodi, 1984]. COAWST explicitly accounts for the influence of flexible cylindrical plant structures on drag and turbulence [Beudin et al., 2017]. Apart from the mean flow velocity, vegetation also modifies turbulence intensity and mixing. The extra dissipation and turbulence kinetic energy production due to vegetation was accounted following Uittenbogaard [2003]. In Delft3D we accounted for vegetation following the Baptist [2005] and Uittenbogaard [2003] formulations for drag and turbulence calculations. The marsh coverage data have been retrieved from the CRSSA's (Center for Remote Sensing and Spatial Analysis) geographic information systems (GIS) database (Figure 1). The marsh coverage data have been retrieved from the CRSSA's (Center for Remote Sensing and Spatial Analysis) geographic information systems (GIS) database (Figure 1). The erosion of salt marshes was 
simulated by removing vegetation from the eroded marsh cells, and by matching the corresponding bathymetry values with the elevation of the surrounding tidal flats. Specifically, when a vegetated 'salt marsh pixel' was adjacent to one or more 'tidal flat pixels', the 'salt marsh pixel' was converted into tidal flat by assigning to it a water depth equivalent to the average of the surrounding 'tidal flat pixels'. The algorithm was repeated enough time to reach a reduction of $25 \%, 50 \%, 75 \%$ and $100 \%$ in the present-day salt marsh area. We used several marsh transects in VCR and Plum Island estuary to check that the 'manipulated' bathymetry could reasonably represent a natural hypsometry after lateral erosion of the marsh edge. Study sites in VCR and Plum Island Sound have eroded due to wind waves. A comparison of several salt marsh transects for these studies and for different years show that lowering marsh platforms to the tidal flat depth is a reasonable representation of how salt marshes might retreat under wind-wave attack. These marsh transects show a flat bathymetry in the eroded areas. As salt marsh removal increases tidal prism values, the mouth of the inlets was updated changing its width through an iterative procedure following the O'Brien-Jarrett-Marchi law [D'Alpaos et al., 2010]. We computed the slope coefficient of the O'Brien-Jarrett-Marchi law [D'Alpaos et al., 2010] with an exponent of 6/7 for the current estuarine morphology and modified the crosssectional area by increasing only the width of the inlets. Convergence of the modified system was considered to have been established once the changes in inlet cross-sectional area modified the tidal prism by less than $1 \%$. For this study, only one class of sediments was defined for all estuaries, with mass density of $2650 \mathrm{~kg} / \mathrm{m} 3$, settling velocity of $0.5 \mathrm{~mm} / \mathrm{s}$, erodibility and critical shear stress equal to $0.0005 \mathrm{~kg} \mathrm{~m}-2 \mathrm{~s}-1$ and $0.05 \mathrm{~N} / \mathrm{m}-2$ respectively; these values were chosen based on sediments fractions parameters typical of lagoon-type estuaries [Wiberg et al., 2015]. The seabed was defined as one layer having an initial thickness of zero. The time frame of the analysis was 30 days. As an initial condition, a uniform suspended sediment concentration $(100 \mathrm{mg} / \mathrm{l})$ was imposed in the water column inside the estuary; specifically, the sediment injection occurs at mean sea level, during the first flood period. During the simulation there are no other external sediment inputs. The amount of sediment initially released in the system does not impact the results, as the main outcomes are expressed in terms of sediment fraction. As the initial sediment thickness at the bottom was zero, sediment transport, erosive and depositional fluxes are solely related to the concentration imposed at the beginning of the simulation. The models were forced with observed tidal forcings and changes in the tidal signal were investigated following classic harmonic analysis [Pawlowicz et al., 2002].

\section{Model validation}

The validation of the models and the adopted parameterizations can be found in the following papers:

\begin{tabular}{|l|l|l|}
\hline Estuarine system & $\begin{array}{l}\text { Relevant reference from } \\
\text { literature }\end{array}$ & Numerical model \\
\hline Plum Island estuary & Zhang et al., 2019 & Delft3D \\
\hline Great South Bay & This study & COAWST \\
\hline Jamaica Bay & This study & COAWST \\
\hline $\begin{array}{l}\text { Barnegat Bay-Little Egg } \\
\text { Harbor estuary }\end{array}$ & Defne \& Ganju, 2014 & COAWST \\
\hline Chincoteague Bay & Beudin et al., 2017 & COAWST \\
\hline Virginia Coast Reserve & Wiberg et al., 2015 & Delft3D \\
\hline
\end{tabular}


Table S1: literature studies dealing with calibration and validation of the numerical models used in this study.

Furthermore, we compared the values in Table A1 of Rinaldo et al., [1999] with the currents over the marsh surface in our models. This comparison presents a good agreement and values are in the same order of magnitude than the ones presented in literature.

\begin{tabular}{|l|l|l|l|}
\hline Estuarine system & $\begin{array}{c}\text { Averaged velocity } \\
\text { during a tidal cycle } \\
(\mathrm{m} / \mathrm{s})\end{array}$ & $\begin{array}{c}\text { Maximum velocity } \\
\text { during a tidal cycle } \\
(\mathrm{m} / \mathrm{s})\end{array}$ & $\begin{array}{c}\text { Current velocity } \\
\text { over salt marsh } \\
\text { surface }(\mathrm{m} / \mathrm{s}), \\
\text { Rinaldo et al., } \\
{[1999]}\end{array}$ \\
\hline Plum Island estuary & 0.02 & 0.06 & $0.05-0.1$ \\
\hline Great South Bay & 0.02 & 0.04 & $0.05-0.1$ \\
\hline Jamaica Bay & 0.03 & 0.09 & $0.05-0.1$ \\
\hline $\begin{array}{l}\text { Barnegat Bay-Little Egg } \\
\text { Harbor estuary }\end{array}$ & 0.01 & 0.03 & $0.05-0.1$ \\
\hline Chincoteague Bay & 0.01 & 0.03 & $0.05-0.1$ \\
\hline Virginia Coast Reserve & 0.02 & 0.05 & $0.05-0.1$ \\
\hline
\end{tabular}

Table S2: validation of current velocities over marsh surfaces.

\subsection{Great South Bay and Jamaica Bay}

Great South Bay and Jamaica Bay have been calibrated in this study. The validation has been carried out for the period with the maximum amount of measurements. Model performance is evaluated using root-squared-error (RMSE), bias and skill scores. The performance levels are categorized as follows: skill $>0.65$ excellent, $0.5-0.65$ very good, and $0.2-0.5$ good; if skill $<0.2$, poor fit.

$$
\begin{gathered}
\text { RMSE }=\left[\frac{1}{N} \sum_{n=1}^{N}\left(\mathrm{X}_{\text {modeled }}-\mathrm{X}_{\text {observed }}\right)^{2}\right]^{1 / 2} \\
\text { Bias }=\frac{1}{N} \sum_{n=1}^{N}\left(\mathrm{X}_{\text {modeled }}-\mathrm{X}_{\text {observed }}\right) \\
\text { skill }=1-\frac{\sum_{n=1}^{N}\left(\mathrm{X}_{\text {modeled }}-\mathrm{X}_{\text {observed }}\right)^{2}}{\sum_{n=1}^{N}\left(\mathrm{X}_{\text {modeled }}-\langle\mathrm{X}\rangle_{\text {observed }}\right)^{2}}
\end{gathered}
$$

The models are forced at the seaward boundaries with tides, using a combination of Flather [1976] and Chapman [1985] boundary conditions; a radiation boundary condition Orlanski [1976] is prescribed on the landward boundary. Bottom shear-stresses are calculated using a quadratic drag law and assuming a logarithmic velocity profile in the bottom grid cell [Warner et al., 2008].

\subsubsection{Great South Bay}

The tidal levels at the boundaries are based on observations from the USGS 01311145 station. The model was calibrated by careful adjustments of the boundary conditions to attain the best agreement between the first 2 weeks post-spin-up model results and water level data measured 
within the estuary. The water level data are collected in seven USGS stations between the 29th July and the 12th August 2018. The model presents excellent agreement with the data.

\begin{tabular}{|l|l|l|l|l|}
\hline & Site & RMSE & Bias & Skill \\
\hline $\begin{array}{l}\text { Water elevation } \\
(\mathrm{m})\end{array}$ & USGS 01311145 & 0.05 & -0.03 & 0.99 \\
\hline $\begin{array}{l}\text { Water elevation } \\
(\mathrm{m})\end{array}$ & USGS 01311143 & 0.09 & -0.08 & 0.97 \\
\hline $\begin{array}{l}\text { Water elevation } \\
(\mathrm{m})\end{array}$ & USGS 01310521 & 0.09 & -0.07 & 0.96 \\
\hline $\begin{array}{l}\text { Water elevation } \\
(\mathrm{m})\end{array}$ & USGS 01310740 & 0.25 & 0.01 & 0.75 \\
\hline $\begin{array}{l}\text { Water elevation } \\
(\mathrm{m})\end{array}$ & USGS 01309225 & 0.06 & 0.02 & 0.79 \\
\hline $\begin{array}{l}\text { Water elevation } \\
(\mathrm{m})\end{array}$ & USGS 01304920 & 0.17 & 0.03 & 0.99 \\
\hline $\begin{array}{l}\text { Water elevation } \\
(\mathrm{m})\end{array}$ & USGS 01304746 & 0.11 & 0.01 & 0.92 \\
\hline
\end{tabular}

Table S3: model performance and skill score for Great South Bay.

\subsubsection{Jamaica Bay}

The tidal levels at the boundaries are based on observations from the USGS station (USGS 01311875) located at the Rockaway Inlet; a factor of 0.97 is applied to the measured water elevations to consider the effects of convergent topography on the tide [Marsooli et al., 2016]. The results of the model are compared with water level data collected in two USGS stations (USGS 01311875 and USGS 01311850) and with flow velocities data measured at the North Channel. During the first two weeks of August 2015. The model presents excellent/very good agreement with the data.

\begin{tabular}{|l|l|l|l|l|}
\hline & Site & RMSE & Bias & Skill \\
\hline $\begin{array}{l}\text { Water elevation } \\
(\mathrm{m})\end{array}$ & $\begin{array}{l}\text { USGS } \\
01311875\end{array}$ & 0.04 & -0.02 & 1 \\
\hline $\begin{array}{l}\text { Water elevation } \\
(\mathrm{m})\end{array}$ & $\begin{array}{l}\text { USGS } \\
01311850\end{array}$ & 0.09 & 0 & 0.99 \\
\hline Ubar $(\mathrm{m} / \mathrm{s})$ & North Channel & 0.17 & -0.08 & 0.63 \\
\hline Vbar $(\mathrm{m} / \mathrm{s})$ & North Channel & 0.09 & -0.05 & 0.83 \\
\hline
\end{tabular}

Table S4: model performance and skill score for Jamaica Bay.

\subsection{Virginia Coast Reserve}

The model of Virginia Coast Reserve was calibrated in two different papers: Wiberg et al., [2015] and Castagno et al., [2018]. The tidal levels at the boundaries are based on observations from the NOAA tide gauge at Wachapreague. The calibration was made by imposing a time shift and amplitude adjustments to the signal on the boundaries.

The model presents excellent agreement with water level data collected at the NOAA station 8631044 between the 1th March 2014 and 11th March 2014. From Castagno et al., [2018]:

\begin{tabular}{|l|l|l|l|}
\hline & Site & RMSE & Skill \\
\hline Water elevation $(\mathrm{m})$ & $\begin{array}{l}\text { NOAA station } \\
8631044\end{array}$ & 0.0624 & 0.9898 \\
\hline
\end{tabular}


Table S5: model performance and skill score for Virginia Coast Reserve.

Furthermore, Wiberg et al., [2015] showed that mean modelled and measured depth-averaged current velocities are almost identical, even though the model tends to underestimate peak velocities $(>30 \mathrm{~cm} / \mathrm{s})$ by $25 \%$. Locations of measurements are depicted in Figure 2 of Wiberg et al., [2015].

\subsection{Barnegat Bay-Little Egg Harbor and Chincoteague Bay}

The model of Barnegat Bay-Little Egg Harbor estuary was calibrated by changing the bottom roughness coefficient to attain the best agreement between model results and water level data and water discharge measurements collected by the U.S. Geological Survey in March 2012 [Defne \& Ganju, 2014].

The model presents very good and excellent agreement with the measurements. From Defne \& Ganju, [2014]:

\begin{tabular}{|l|l|l|l|}
\hline & Site & RMSE & Skill \\
\hline $\begin{array}{l}\text { Water elevation } \\
(\mathrm{m})\end{array}$ & USGS 01408167 & 0.10 & 0.55 \\
\hline $\begin{array}{l}\text { Water elevation } \\
(\mathrm{m})\end{array}$ & USGS 01408750 & 0.09 & 0.57 \\
\hline $\begin{array}{l}\text { Water elevation } \\
(\mathrm{m})\end{array}$ & USGS 01408205 & 0.09 & 0.53 \\
\hline $\begin{array}{l}\text { Water elevation } \\
(\mathrm{m})\end{array}$ & USGS 01409110 & 0.09 & 0.50 \\
\hline $\begin{array}{l}\text { Water elevation } \\
(\mathrm{m})\end{array}$ & USGS 01409147 & 0.10 & 0.86 \\
\hline $\begin{array}{l}\text { Water elevation } \\
(\mathrm{m})\end{array}$ & USGS 01409146 & 0.13 & 0.59 \\
\hline $\begin{array}{l}\text { Water elevation } \\
(\mathrm{m})\end{array}$ & USGS 01409335 & 0.15 & 0.93 \\
\hline $\begin{array}{l}\text { Tidal discharge } \\
\text { magnitude }(\mathrm{m} 3 / \mathrm{s})\end{array}$ & USGS 01408043 & 53 & 0.88 \\
\hline $\begin{array}{l}\text { Tidal discharge } \\
\text { magnitude (m3/s) }\end{array}$ & USGS 01409125 & 567 & 0.5 \\
\hline $\begin{array}{l}\text { Tidal discharge } \\
\text { magnitude (m3/s) }\end{array}$ & USGS 0140914550 & 192 & \\
\hline
\end{tabular}

Table S6: model performance and skill score for Barnegat Bay-Little Egg Harbor estuary.

The model of Chincoteague Bay was extensively calibrated in two papers: Ganju et al., [2016] and Beudin et al., [2017]. Ganju et al., [2016] evaluated bed elevation changes induced by storms, while Beudin et al., [2017] investigated the physical response of the bay to a posttropical cyclone.

From Beudin et al., [2017]:

\begin{tabular}{|l|l|l|l|}
\hline & Site & RMSE & Skill \\
\hline Water Level $(\mathrm{m})$ & NOAA 8570283 & 0.19 & 0.74 \\
\hline Water Level $(\mathrm{m})$ & $\begin{array}{l}\text { Public Landing } \\
\text { Maryland DNR }\end{array}$ & 0.16 & 0.74 \\
\hline
\end{tabular}




\begin{tabular}{|l|l|l|l|}
\hline & $\begin{array}{l}\text { station (-75.2862, } \\
38.1483)\end{array}$ & & \\
\hline Water Level (m) & USGS 01484746 & 0.15 & 0.84 \\
\hline
\end{tabular}

Table S7: model performance and skill score for Chincoteague Bay.

\subsection{Calibration and sensitivity analysis of sediment trapping capacity with respect to model calibration parameters for Plum Island estuary.}

Variations in calibration parameters can have a strong effect on import and export of sediments [Vermeulen, 2003]. Here we will test whether different model calibrations can significantly change the sediment trapping capacity of the bays. We choose Plum Island Sound, Massachusetts, as a test case (Fig. S1). As indicated by Cunge [2003], model calibration relies on careful adjustment of the tidal boundary conditions. This is consistent with the results of Abbott and Cunge [1975] who showed that adjusting the boundary conditions, rather than adjusting friction, was a more reliable approach to the calibration of estuary models. Here we will use three different calibrations (i.e. three different boundary conditions) of the numerical model and compute possible differences in sediment trapping capacity.

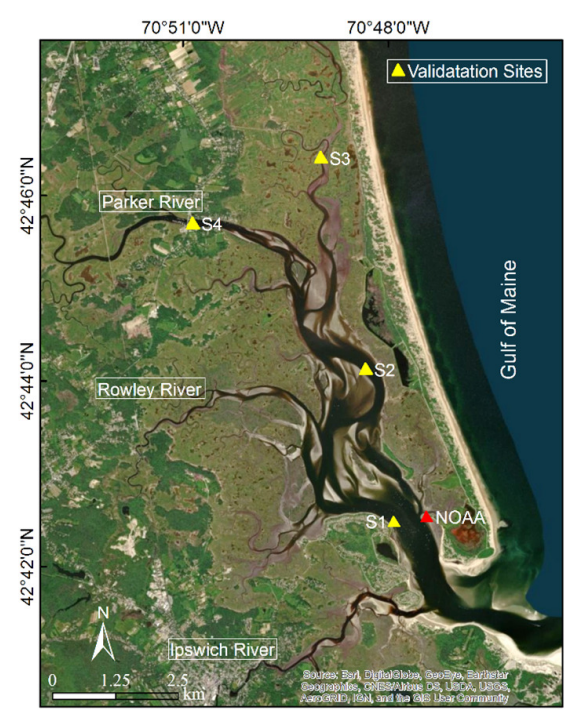

Figure S1: locations of water level observation sites for model validation. S1 tidal station is at Ipswich Bay Yacht Club pier, S4 tidal station is in the Parker River near Route 1A Bridge. S1 and S4 belong to PIE-LTER, S2 and S3 are ADCP measurement sites in 2010 and 2017 respectively. The NOAA station 8441241 is indicated with a red triangle.

The first boundary condition is obtained by modifying tidal harmonics and phases of the NOAA station (8441241) in the Sound. This tidal signal is then set as boundary condition at the ocean side of the domain, as it was done in Zhang et al., [2019]. The second method is to use a spatially varying tidal boundary condition derived directly from the large scale ADCIRC model results along the Atlantic coast [Szpilka et al., 2016]. The resolution of ADCIRC Version ec2015 at our model boundary is about 400-600 $\mathrm{m}$ and our model mesh resolution is $25 \mathrm{~m}$. The last method is based on a modification of tidal harmonics and phases derived from the ADCIRC model results, to account for possible errors in complex coastal bathymetries. The mean relative amplitude errors of ADCIRC is between $8.5 \%$ and $20 \%$, and phase errors are around $10^{\circ}$ in the Atlantic Ocean [Szpilka et al., 2016]. These errors warrant an ad hoc calibration for small-scale systems like Plum Island Sound. Four long-term series field 
measurements are used for validation. As showed in Fig.S1, S1 tidal station is at Ipswich Bay Yacht Club pier, and the harmonics are calculated from measurement of water level every 15 minutes from 00:00 April 01, 2016 to 00:00 November 01, 2016. S4 tidal station is in the Parker River near Route 1A Bridge, and the harmonics are calculated from water levels measured every 15 minutes from 10:00 April 11, 2002 to 12:00 December 05, 2002. S1 and S4 datasets belong to PIE-LTER. S2 and S3 are water levels collected with an Acoustic Doppler Current Profiler (ADCP) in 2010 (every 30 minutes from 12:00 July 20, 2010 to 09:00 September 11, 2010) and 2017 (every 10 minutes from 08:00 September 08, 2017 to 19:00 October 14, 2017) respectively. Fig. S2 shows amplitude difference (A) and phase difference (B) of dominant tidal harmonics $\left(\mathrm{M}_{2}, \mathrm{~S}_{2}, \mathrm{~N}_{2}, \mathrm{O}_{1}, \mathrm{~K}_{1}\right)$ at these four validation sites. The third calibration method (ADCRIC2 indicated in blue markers) modifies the ADCIRC boundary conditions by subtracting the average difference in amplitude and phase of each harmonic between field measurements and model results at four observation sites. This calibration method significantly improves model accuracy with a harmonic amplitude less than $5 \mathrm{~cm}$ and phase difference less than $5^{\circ}$ between filed measurements and model results. ADCIRC2 perform best, followed by NOAA and ADCIRC1 respectively (Fig. S2). The calibrated harmonics are reported in Table S7.

\begin{tabular}{lllllllllll}
\hline & $\mathrm{M}_{2}(\mathrm{~m})$ & $\mathrm{M}_{2}\left({ }^{\circ}\right)$ & $\mathrm{S}_{2}(\mathrm{~m})$ & $\mathrm{S}_{2}\left({ }^{\circ}\right)$ & $\mathrm{N}_{2}(\mathrm{~m})$ & $\mathrm{N}_{2}\left(^{\circ}\right)$ & $\mathrm{K}_{1}(\mathrm{~m})$ & $\mathrm{K}_{1}\left({ }^{\circ}\right)$ & $\mathrm{O}_{1}(\mathrm{~m})$ & $\mathrm{O}_{1}\left({ }^{\circ}\right)$ \\
\hline NOAA & 1.28 & 100.90 & 0.16 & 151.10 & 0.27 & 72.20 & 0.13 & 196.80 & 0.11 & 183.90 \\
ADCIR1 & 1.34 & 108.52 & 0.19 & 140.79 & 0.28 & 72.90 & 0.12 & 193.71 & 0.10 & 190.02 \\
ADCIR2 & 1.30 & 98.52 & 0.18 & 131.68 & 0.27 & 64.81 & 0.13 & 198.84 & 0.12 & 183.63 \\
\hline
\end{tabular}

Table S8: tidal harmonics of different calibration methods, note values of ADCIR1 and ADCIR2 are mean values of three tidal boundaries.

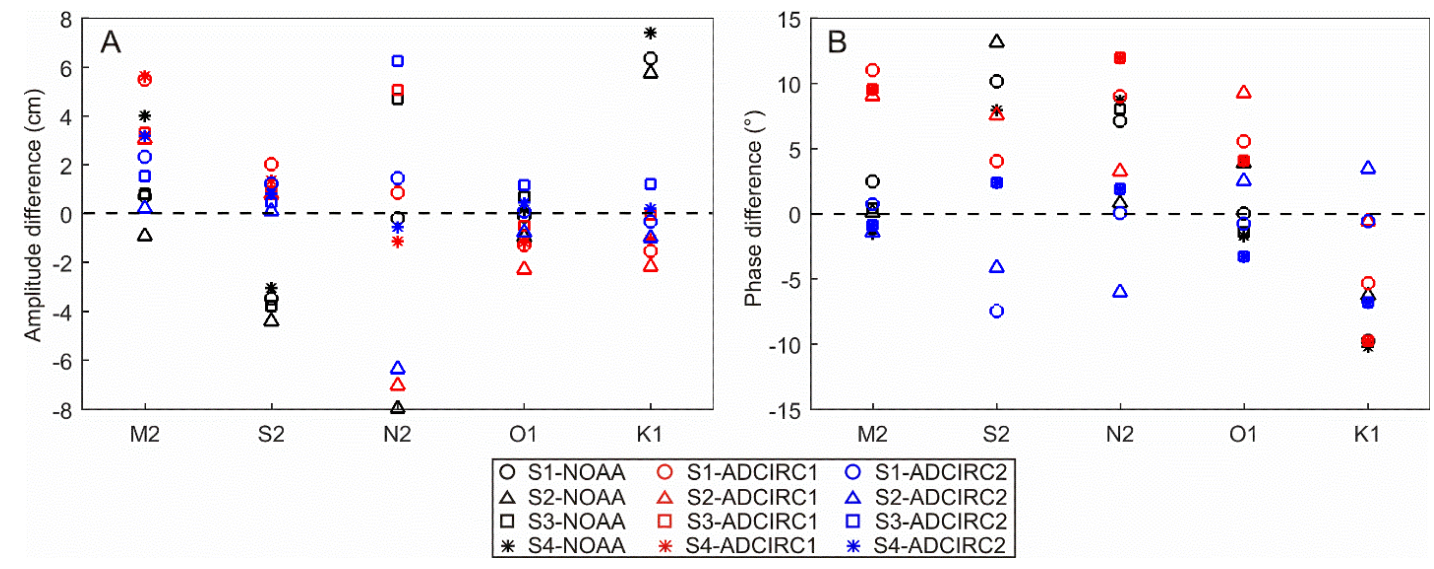

Figure S2: amplitude difference (A) and Phase difference (B) of principal tidal harmonics $\left(\mathrm{M}_{2}\right.$, $\mathrm{S}_{2}, \mathrm{~N}_{2}, \mathrm{O}_{1}, \mathrm{~K}_{1}$ ) at validation sites $\mathrm{S} 1$ (circle), S2 (triangle), S3 (square), S4 (Asterisk) (see Fig.S1) with three different tidal boundary conditions (Table S1). S-NOAA results are obtained by modifying the tidal harmonics and phases of NOAA station (8441241), and are indicated as black markers in the figure; S-ADCIRC1 are obtained with tidal harmonics and phases derived from ADCIRC model results in the Atlantic Ocean [Szpilka et al., 2016] (red markers); SADCIRC2 results are obtained by modifying tidal harmonics and phases of ADCIRC (blue markers).

We then test the sensitivity of sediment trapping capacity of the bay with respect the different calibration methods mentioned above. With each boundary condition, uniform sediments are 
released in bay water for five marsh-removal scenarios, removing 25\%, 50\%, 75\%, and 100\% of the marshes (STAN, STAN-25\%, STAN-50 \%, STAN-75 \%, STAN-100 \%). Figure S3 shows the percent difference in trapping capacity between different calibration strategies for the five marsh removal scenarios. The maximum difference is only $3 \%$, indicating that the trapping capacity computed by the model is robust and minimally affected by the calibration parameters.

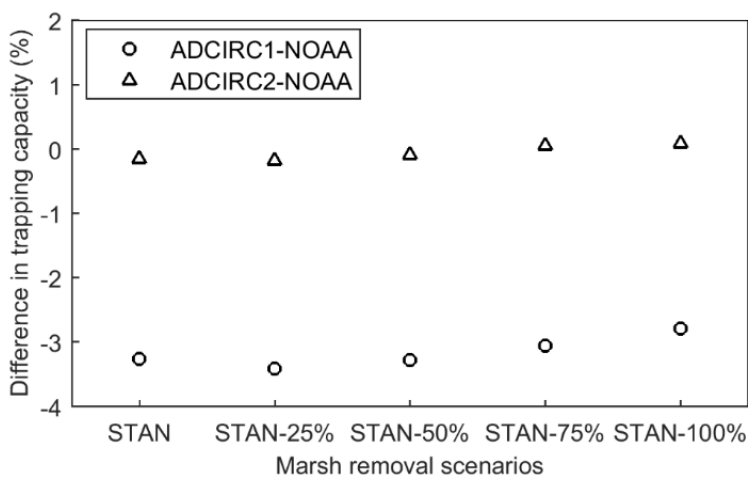

Figure S3: difference in trapping capacity of Plum Island Sound between the calibration using NOAA harmonics and ADCIRC1 harmonics (ADCIRC2 - NOAA) and between NOAA harmonics and ADCIRC2 harmonics (ADCIRC2-NOAA) for different marsh-removal scenarios (STAN, STAN-25 \%, STAN-50 \%, STAN-75 \%, STAN-100 \%).

\section{Calculation of variables in 'Figure 3'}

$\mathrm{D}=$ sediment deposit on tidal flats $[\mathrm{kg}]$. Scenario: $0 \%, 25 \%, 50 \%$ and $75 \%$ marsh loss.

$\mathrm{D}_{100}(<\mathrm{D})=$ sediment deposit on tidal flats $[\mathrm{kg}]$. Scenario: $100 \%$ marsh loss.

$\mathrm{T}=$ sediment input initially released in the system $[\mathrm{kg}]$.

$\mathrm{A}=$ tidal flat area $\left[\mathrm{m}^{2}\right]$.

$M=$ sediment deposit on salt marshes [kg]. Scenario: $0 \%, 25 \%, 50 \%$ and $75 \%$.

$\mathrm{B}=$ salt marsh area $\left[\mathrm{m}^{2}\right]$.

- fraction of sediment on tidal flats and channels per unit area directly related to marsh presence $=$

$$
\frac{D-D_{100}}{T} \frac{1}{A}
$$

- $\quad$ fraction of sediment on salt marshes per unit area $=$

$$
\frac{M}{T} \frac{1}{B}
$$




\begin{tabular}{|c|c|c|}
\hline Estuarine system & $\begin{array}{c}\text { Total amount of sediment } \\
\text { released }(\mathbf{k g})\end{array}$ & $\begin{array}{c}\text { Tidal prism }\left(\mathbf{m}^{\mathbf{3}}\right) \mathbf{1 0 0 \%} \\
\text { marsh loss }\end{array}$ \\
\hline Plum Island estuary & $4.01 \cdot 10^{6}$ & $8.3 \cdot 10^{7}$ \\
\hline Great South Bay & $1.08 \cdot 10^{8}$ & $6.3 \cdot 10^{8}$ \\
\hline $\begin{array}{c}\text { Jamaica Bay } \\
\text { Barnegat Bay-Little Egg Harbor } \\
\text { estuary }\end{array}$ & $3.94 \cdot 10^{7}$ & $3.9 \cdot 10^{8}$ \\
\hline $\begin{array}{c}\text { Chincoteague Bay } \\
\text { Virginia Coast Reserve }\end{array}$ & $8.16 \cdot 10^{7}$ & $2.5 \cdot 10^{8}$ \\
\hline
\end{tabular}

Table S9: amount of sediment initially released in the system $(\mathrm{kg})$, tidal prism $(\mathrm{m} 3)$ in the configuration with $100 \%$ marsh loss. 


\section{Figure captions from Figure S4 to Figure S14}

Figure S4: bathymetry of Plum Island Sound and Great South Bay; colour maps refer to depths below MSL (a, f); model domains: current salt marsh distribution (b, g) and marsh completely eroded (c, h); $\mathrm{M}_{2}$ amplitude $(\mathrm{cm})$ and phase lag $\left({ }^{0}\right)$ for the $0 \%$ erosion case (d-e, i-l). Missing plots are to be found in Figures 2 and 3.

Figure S5: bathymetry of Jamaica Bay and Barnegat Bay-Little Egg Harbor; colour maps refer to depths below MSL $(a, h)$; model domains: current salt marsh distribution (b, i) and marsh completely eroded (c, 1$) ; \mathrm{M}_{2}$ amplitude $(\mathrm{cm})$ and phase lag $\left({ }^{\circ}\right)$ for the $0 \%$ erosion case (d-e, m$\mathrm{n})$; reduction in $\mathrm{M}_{2}$ amplitude $(\mathrm{cm})$ and increase in phase lag $(\Phi)$ after the removal of the entire marsh surface (f-g, o-p).

Figure S6: bathymetry of Chincoteague Bay (a), the colour map refer to depths below MSL; model domains: current salt marsh distribution (b) and marsh completely eroded (c); $\mathrm{M}_{2}$ amplitude (cm) and phase lag $\left({ }^{0}\right)$ for the $0 \%$ erosion case (d-e); reduction in $\mathrm{M}_{2}$ amplitude $(\mathrm{cm})$ and increase in phase lag $(\Phi)$ after the removal of the entire marsh surface (f-g).

Figure S7: bathymetry of Virginia Coast Reserve, the colour map refer to depths below MSL (a); model domains: current salt marsh distribution (b) and marsh completely eroded (c); $\mathrm{M}_{2}$ amplitude (cm) and phase lag $\left({ }^{0}\right)$ for the $0 \%$ erosion case (d-e); reduction in $\mathrm{M}_{2}$ amplitude $(\mathrm{cm})$ and increase in phase lag $(\Phi)$ after the removal of the entire marsh surface (f-g).

Figure S8: relative change in tidal prism as a function of normalized marsh area. The four values for each location are the four quartiles tested $(0,25,50$ and $75 \%)$.

Figure S9: $\mathrm{M}_{2}$ amplitude $(\mathrm{cm})$ for the $0 \%$ erosion case with closed inlet 2 and 3 (a), closed inlet 1 and 3 (c), closed inlet 1 and 2 (e); difference in $\mathrm{M}_{2}$ amplitude $(\mathrm{cm})$ between the case with the current salt marsh extent and with salt marshes completely eroded with closed inlet 2 and 3 (b), closed inlet 1 and 3 (d), closed inlet 1 and 2 (f) in Great South Bay.

Figure S10: $\mathrm{M}_{2}$ amplitude $(\mathrm{cm})$ for the $0 \%$ erosion case with closed inlet 1 (a) and closed inlet 2 (c); difference in $\mathrm{M}_{2}$ amplitude $(\mathrm{cm})$ between the case with the current salt marsh extent and with salt marshes completely eroded with closed inlet 1 (b) and closed inlet 2 (d), in Chincoteague Bay.

Figure S11: $\mathrm{M}_{2}$ amplitude $(\mathrm{cm})$ for the $0 \%$ erosion case with inlet 1 opened (a), inlet 2 opened (c), inlet 3 opened (e), inlet 4 opened (g), inlet 5 opened (i); difference in $\mathrm{M}_{2}$ amplitude (cm) between the case with the current salt marsh extent and with salt marshes completely eroded with inlet 1 opened (b), inlet 2 opened (d), inlet 3 opened (f), inlet 4 opened (h) and inlet 5 opened (1) in Virginia Coast Reserve.

Figure S12: sea-surface $\mathrm{M}_{4} / \mathrm{M}_{2}$ amplitude ratio for the current marsh distribution $(\mathrm{a}, \mathrm{c})$ and marsh completely eroded (b, d) in Plum Island Sound and Great South Bay respectively. Missing plots are to be found in Figures 2 and 3.

Figure S13: sea-surface amplitude ratio for the current marsh distribution (a, e) and marsh completely eroded (b, f); sea-surface phase of $\mathrm{M}_{4}$ relative to $\mathrm{M}_{2}$ for the current marsh distribution (c, g) and marsh completely eroded $(\mathrm{d}, \mathrm{h})$ in Jamaica Bay and Barnegat Bay-Little Egg Harbor respectively. 
Figure S14: sea-surface amplitude ratio for the current marsh distribution (a, e) and marsh completely eroded $(b, f)$; sea-surface phase of $M_{4}$ relative to $M_{2}$ for the current marsh distribution (c, g) and marsh completely eroded $(\mathrm{d}, \mathrm{h})$ in Chincoteague Bay and Virginia Coast Reserve. 


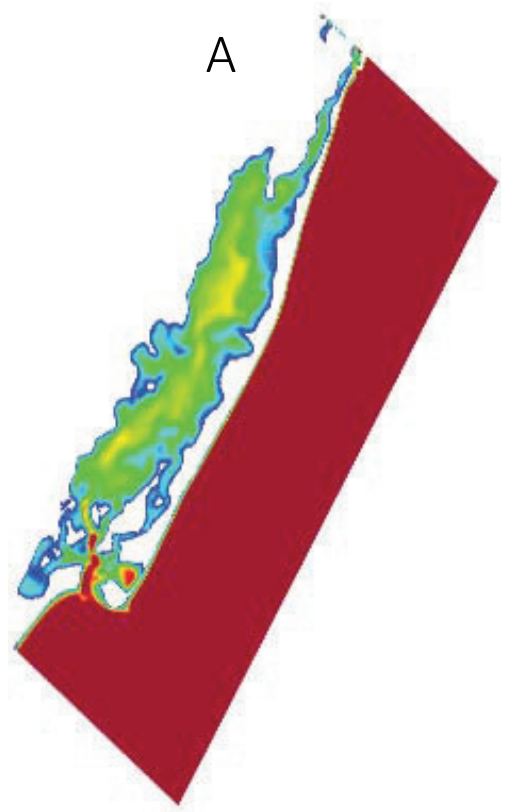

Bathymetry (m.s.l.)
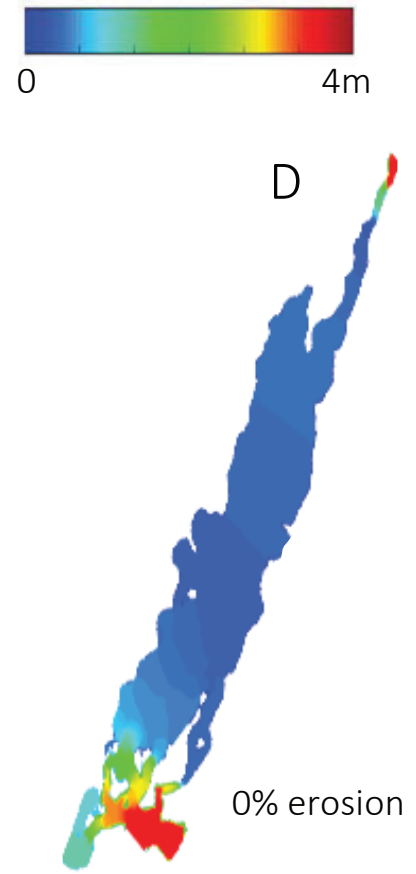
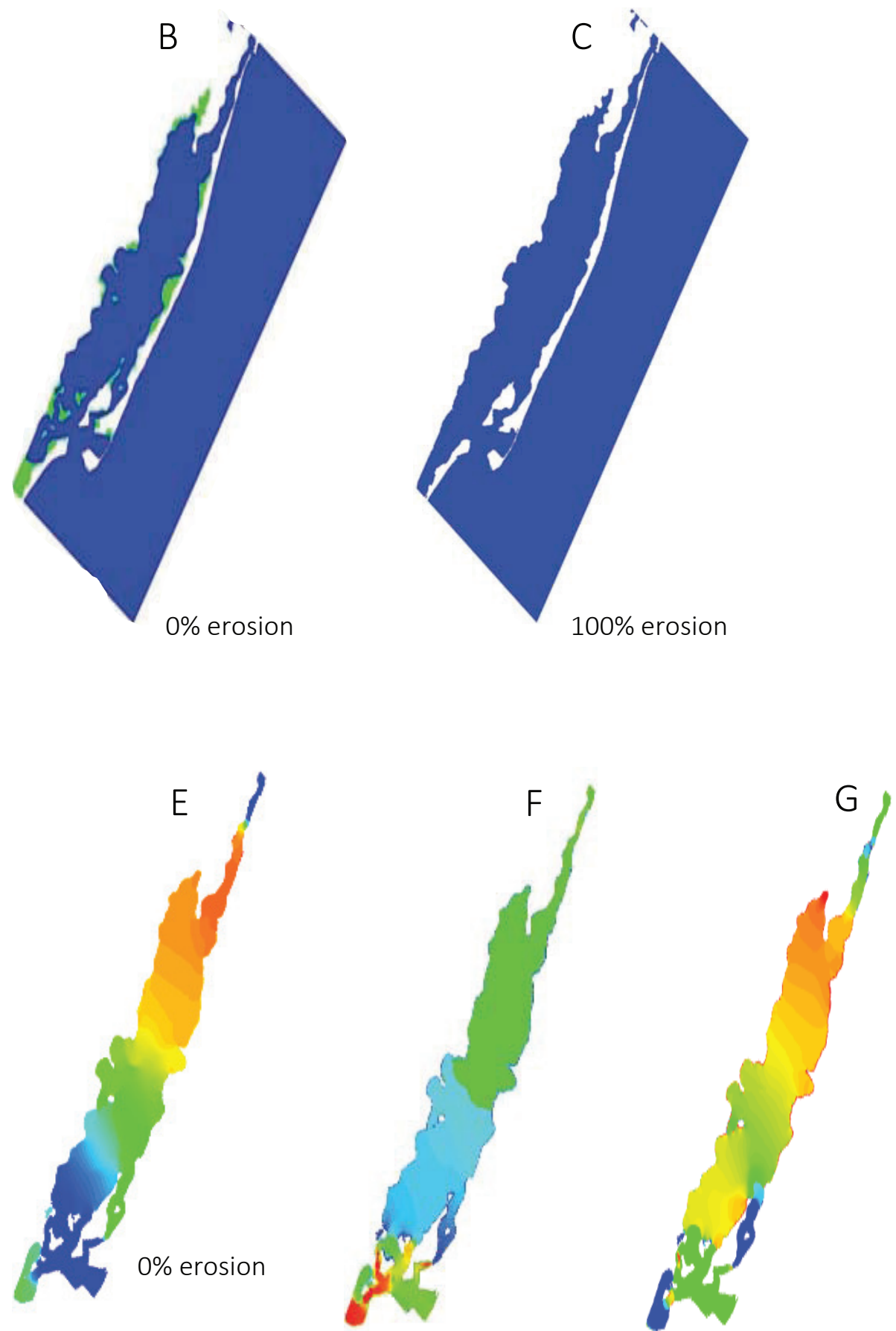

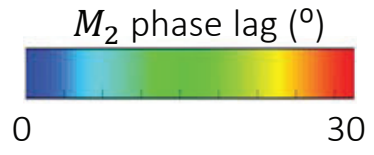

$M_{2}$ amplitude reduction $(\mathrm{cm})$

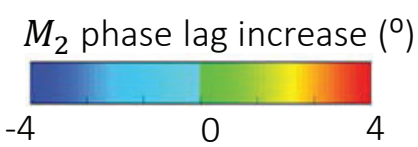




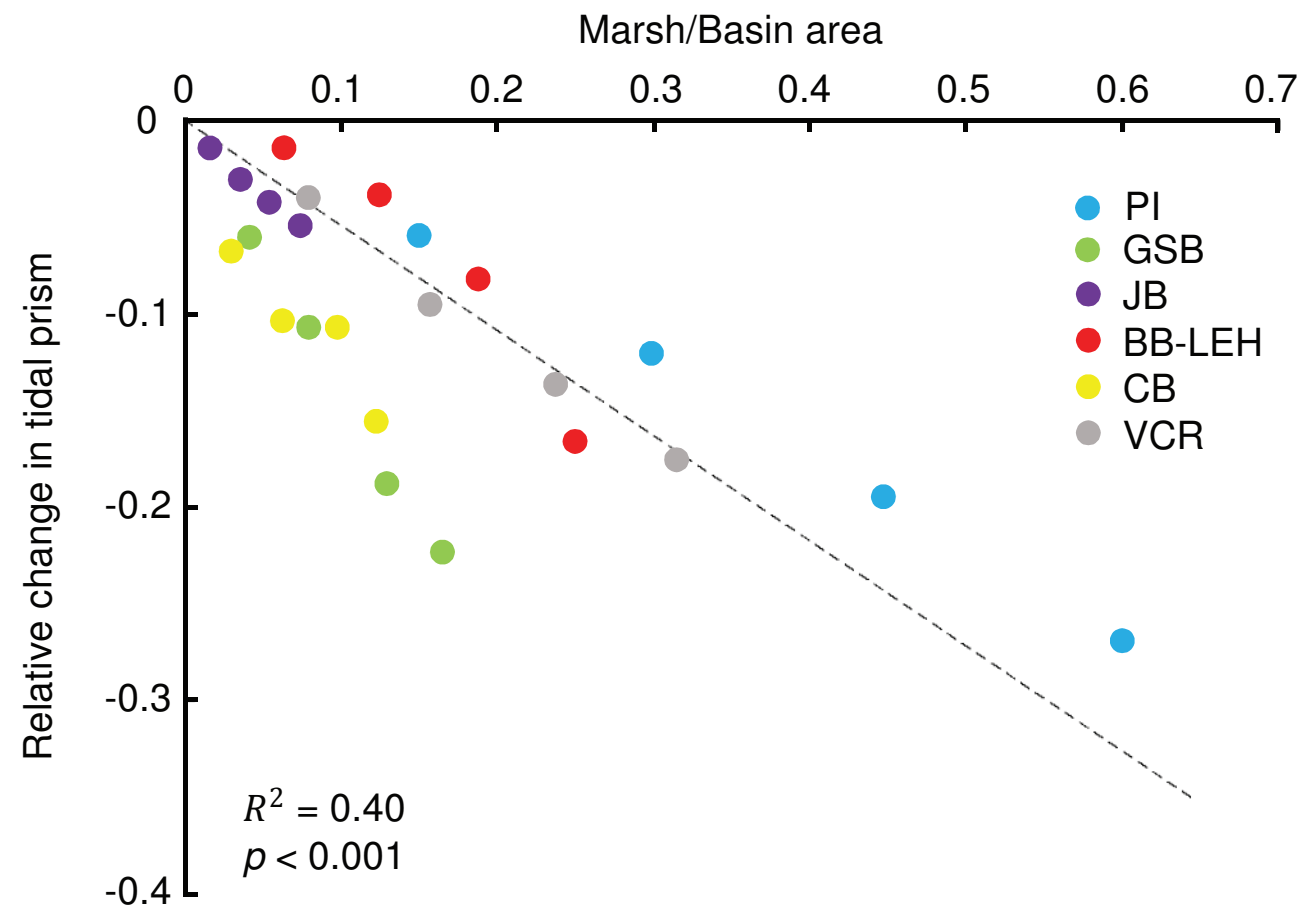




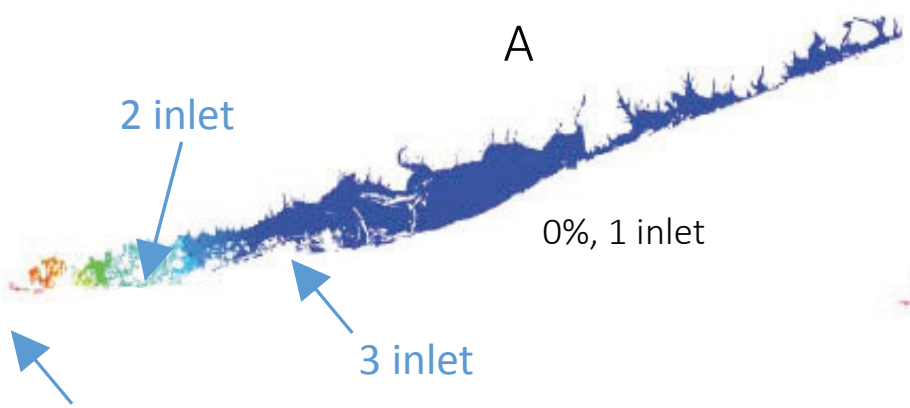

B

1 inlet
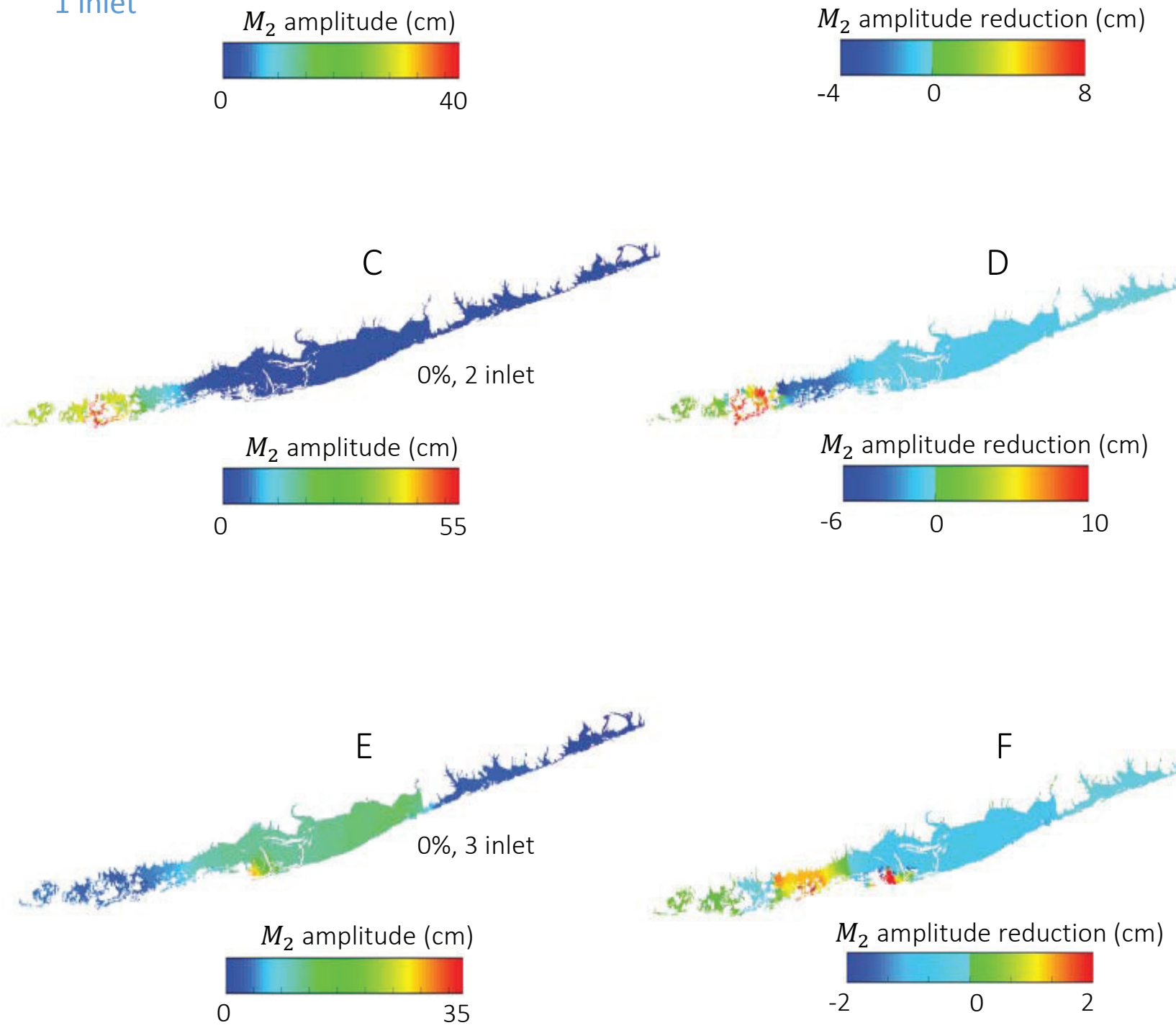

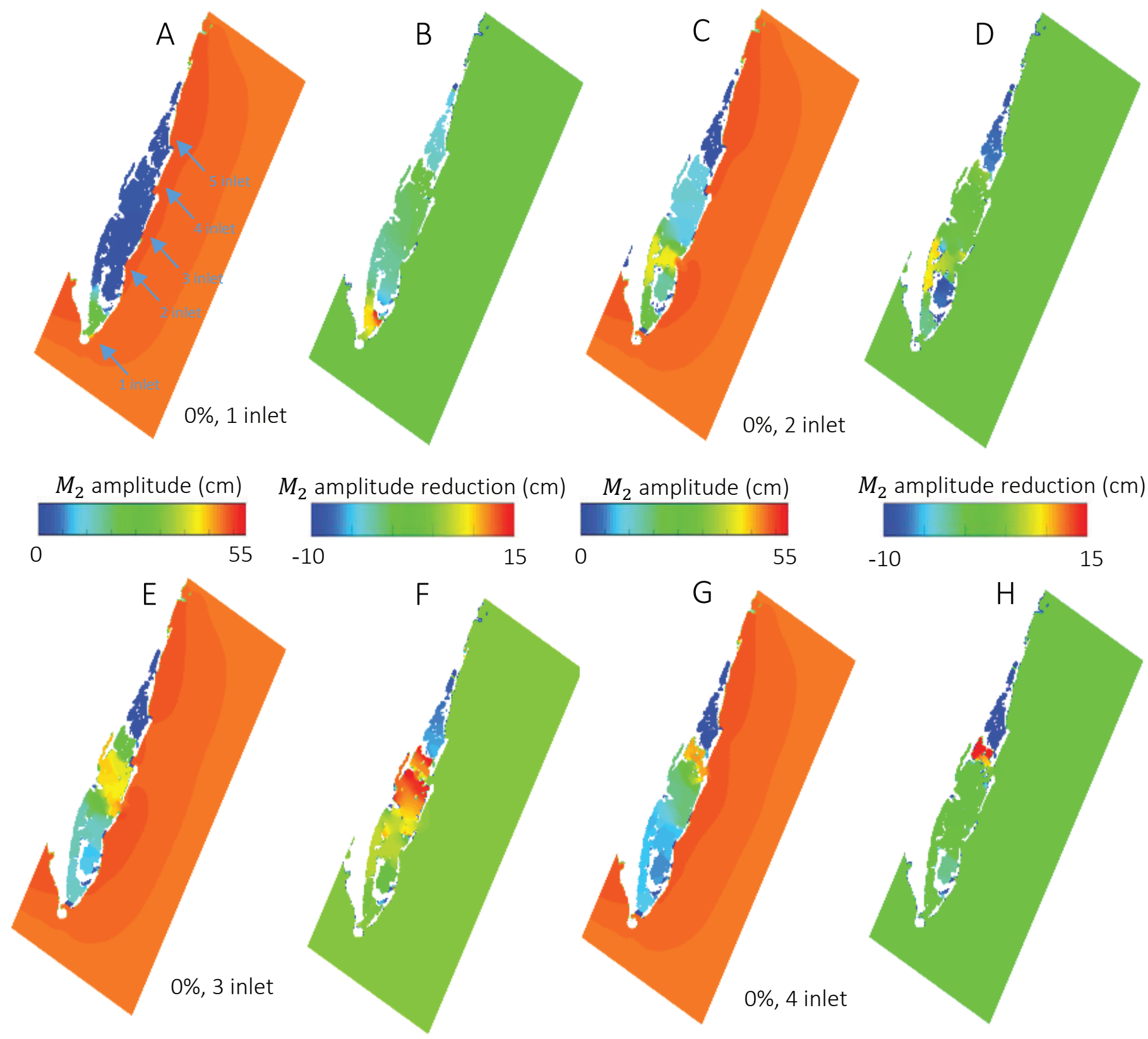

$M_{2}$ amplitude reduction (cm)

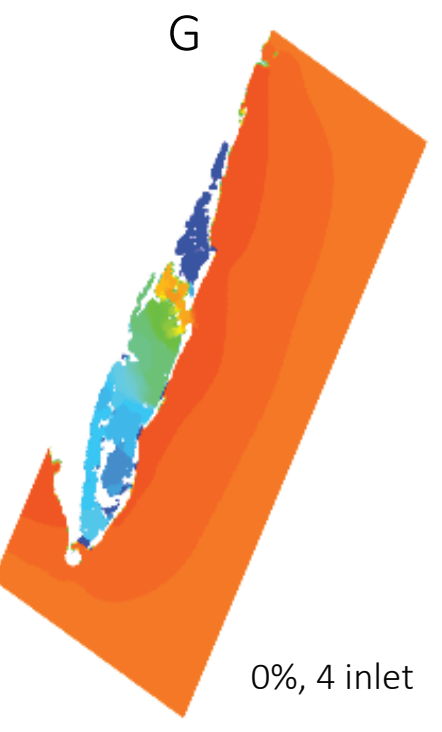

$-10$ 15
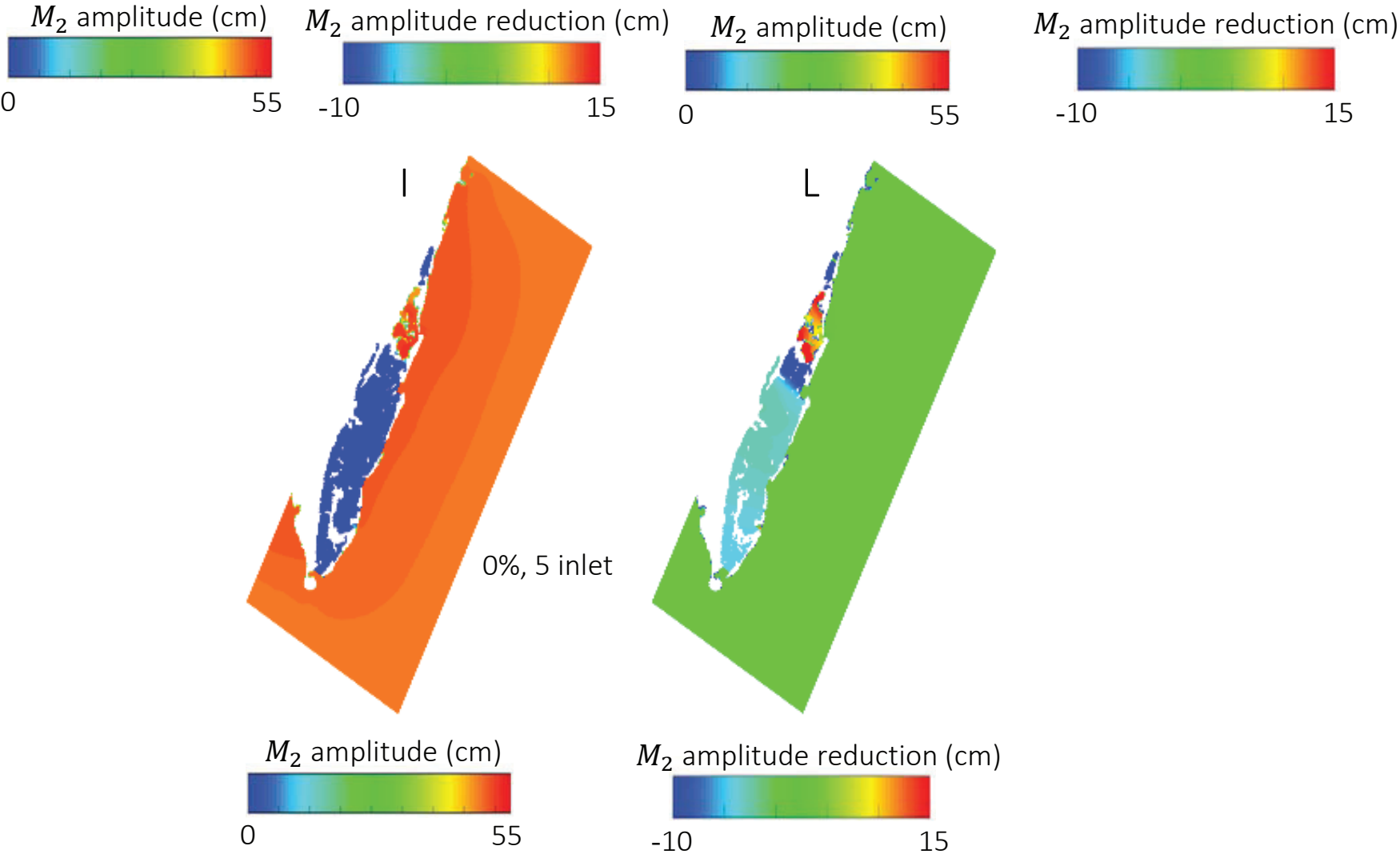

$M_{2}$ amplitude reduction ( $\mathrm{cm}$ ) 

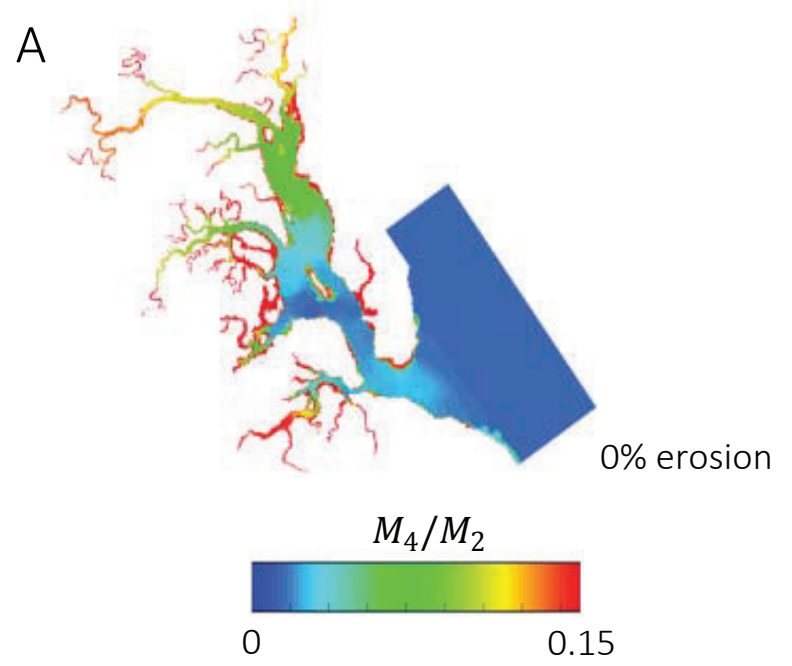

C

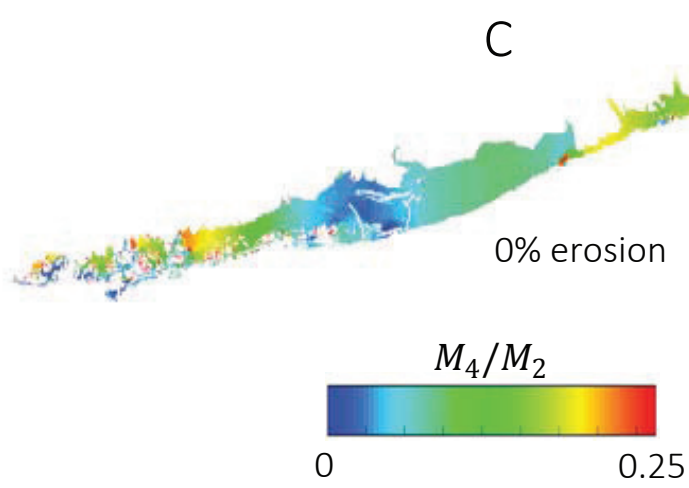

B
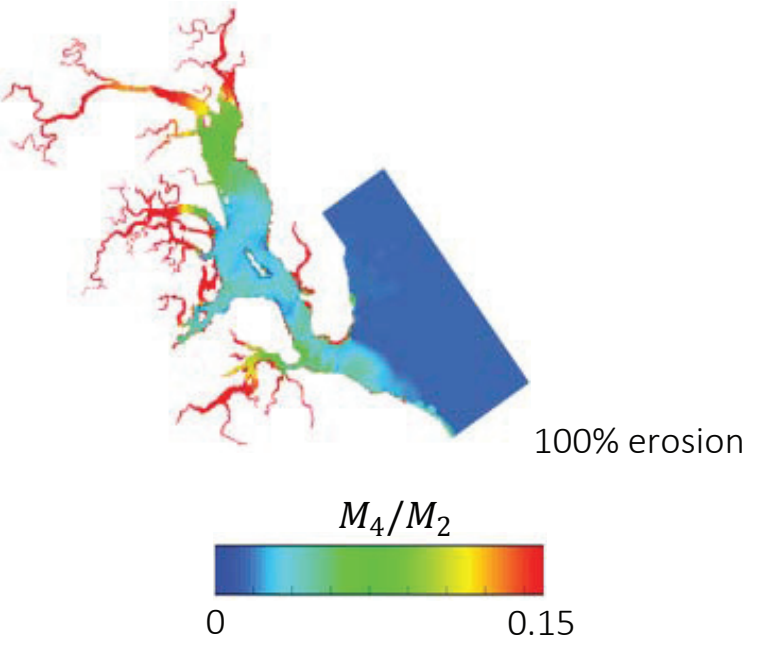

D

$100 \%$ erosion

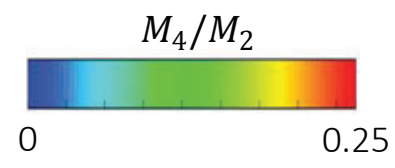




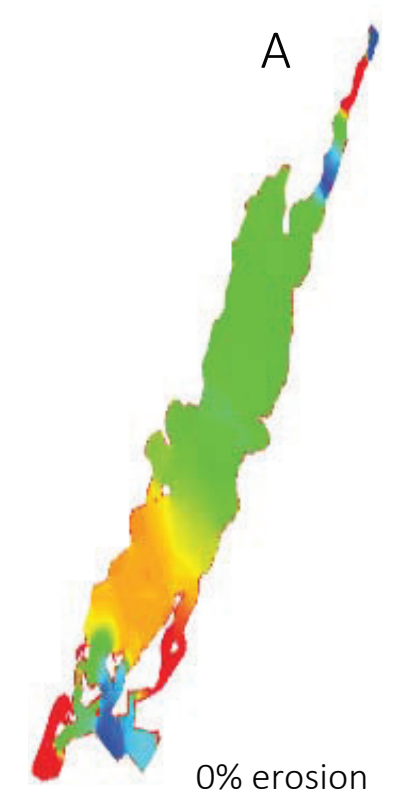

$0 \%$ erosion
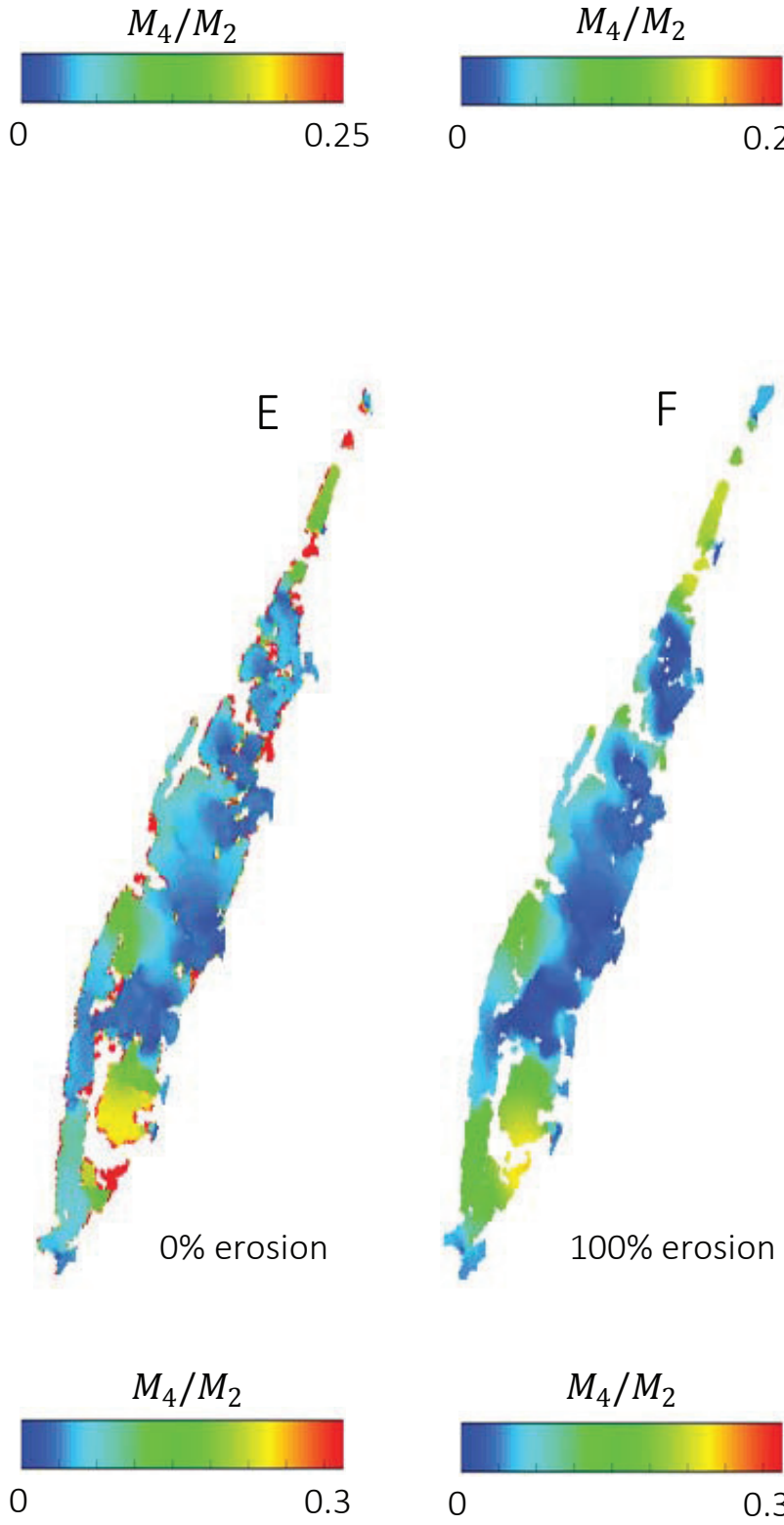
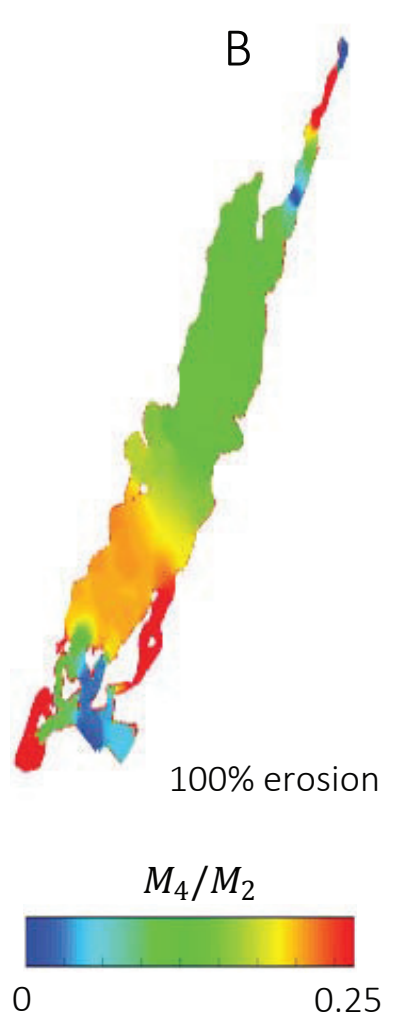

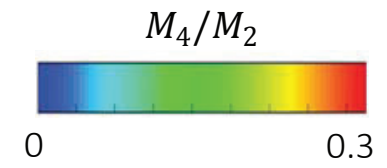

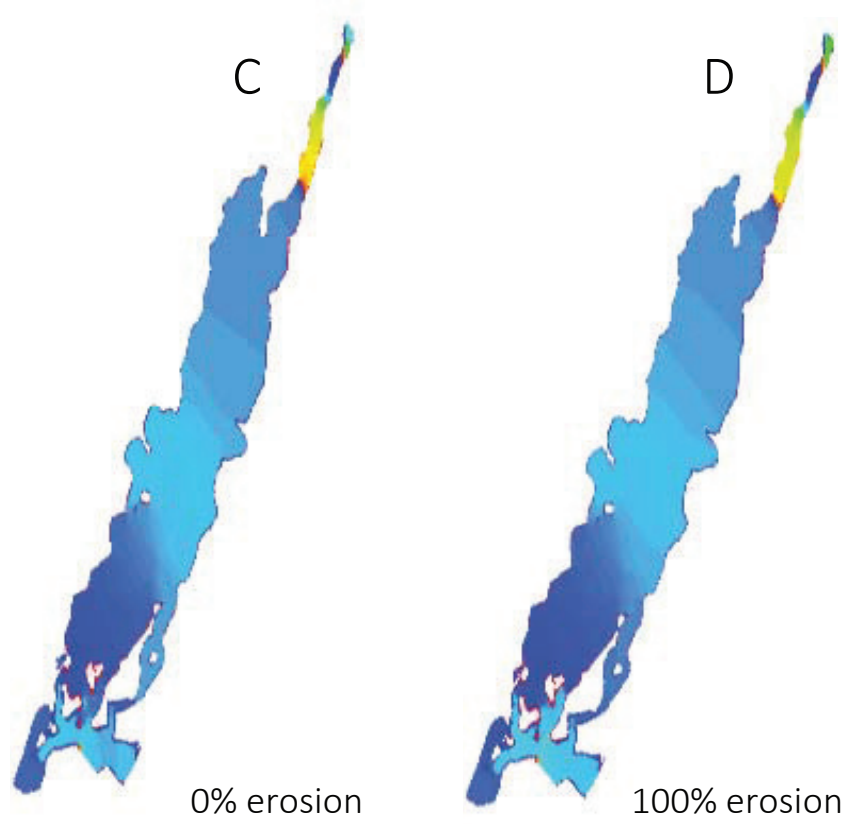
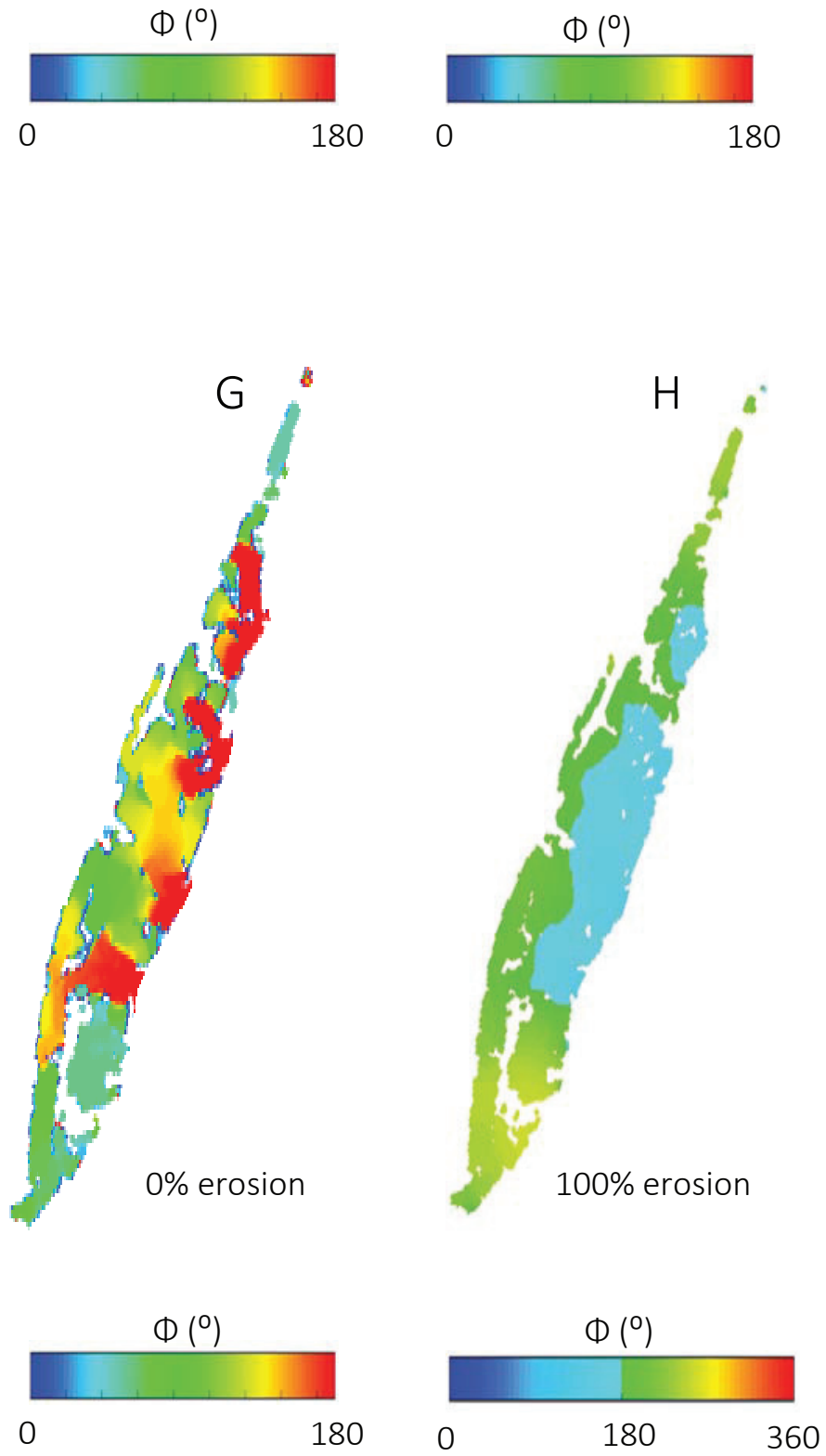


\section{References}

Abbott, M.B., and Cunge, J.A., (1975). Two-dimensional modelling of tidal deltas and estuaries, case study: River Seine Estuary Coarse Grid Model, In: Unsteady Flows in Open Channels, Series, Mahmood K and Yevhevich V (eds), pp. 795-799, Water Res. Publications.

Ariathurai, C.R., and Arulanandan, K., (1978). Erosion rates of cohesive soils. Journal of Hydraulics Division, 104 (2), pp. 279-282.

Baptist, M. J., (2005), Modelling floodplain biogeomorphology, TU Delft, Delft University of 357 Technology.

Beudin, A., Kalra, T. S., Ganju, N. K., and Warner, J. C., (2017). Development of a coupled wave-flow vegetation interaction model. Computers \& Geosciences.

Beudin, A., Ganju, N. K., Defne, Z., and Aretxabaleta, A. L., (2017). Physical response of a back-barrier estuary to a post-tropical cyclone. Journal of Geophysical Research: Oceans, 122, 5888-5904. https://doi.org/10.1002/2016JC012344.

Castagno, K.A., Jiménez-Robles, A.M., Donnelly, J.P., Wiberg, P.L., Fenster, M.S., and Fagherazzi, S., (2018). Intense storms increase the stability of tidal bays. Geophysical Research Letters.

Chapman, D.C., (1985). Numerical treatment of cross-shelf open boundaries in a barotropic coastal ocean model, J. Phys. Oceanogr., 15, 1060-1075.

Cunge, J.A., (2003). Of data and models. Journal of Hydroinformatics, 5 (2), 75-98. Szpilka, C., Dresback, K., Kolar, R., Feyen, J., \& Wang, J. (2016). Improvements for the western north atlantic, caribbean and gulf of mexico adcirc tidal database (EC2015). Journal of Marine Science and Engineering, 4(4), 72.

Defne, Z., and Ganju, N., (2014). Quantifying the residence time and flushing characteristics of a shallow, back-barrier estuary: Application of hydrodynamic and particle tracking models, Estuaries Coasts,1-16, doi:10.1007/s12237-014-9885-3.

D'Alpaos, A., Lanzoni, S., Marani, M., and Rinaldo, A., (2010). On the tidal prism-channel area relations. Journal of Geophysical Research, 115. F01003doi:10.1029/2008JF001243.

Flather, R. A., (1976). A tidal model of the northwest European continental shelf, Mem. Soc. R. Sci. Liege, 6, 141-164.

Ganju, N.K., Suttles, S.E., Beudin, A., Nowacki, D.J., Miselis, J.L., and Andrews, B.D., (2017). Quantification of storm-induced bathymetric change in a back-barrier estuary, Estuaries Coasts, 40(1), 22- 36.

Lesser, G. R., Roelvink, J. A., van Kester, J. A. T. M., and Stelling, G. S., (2004). Development and validation of a three-dimensional morphological model. Coastal Engineering, 51(8-9), 883-915. https://doi.org/10.1016/j.coastleng.2004.07.014.

Marsooli, R., Orton, P.M., Georgas, N., Blumberg, A.F, (2016). Three-dimensional hydrodynamic modeling of coastal flood mitigation by wetlands. Coast. Eng., 111, pp. 83-94 
Orlanski, I., (1976). A simple boundary condition for unbounded hyperbolic flows, J. Comp. Sci., 21(3), 251-269.

Partheniades, E., (1965). Erosion and deposition of cohesive soils, Journal of the Hydraulics 414 Division, 91(1), 105-139.

Pawlowicz, R., B. Beardsley, and Lentz, S., (2002). Classical tidal harmonic analysis including error estimates in MATLAB using T_TIDE, Comput. Geosci., 28, 929-937.

Rinaldo, A., Fagherazzi, S., Lanzoni, S., Marani, M., and Dietrich, W. E., (1999), Tidal networks: 2. Watershed delineation and comparative network morphology, Water Resour. Res., 35(12), 3905-3917, doi:10.1029/1999WR900237.

Rodi, W., (1984). Turbulence models and their application in hydrulicsm a state of the art review. Technical report, International Association of Hydraulics Research, Delft.

Shchepetkin, A. F., and McWilliams, J. C., (2005). The Regional Ocean Modeling System: A split-explicit, free-surface, topography following coordinates ocean model, Ocean Modelling, 9, 347-404.

Szpilka, C., Dresback, K., Kolar, R., Feyen, J., and Wang, J., (2016). Improvements for the Western North Atlantic, Caribbean and Gulf of Mexico ADCIRC Tidal Database (EC2015). J. Mar. Sci. Eng. 2016, 4, 72.

Uittenbogaard R., (2003). Modelling turbulence in vegetated aquatic flows. International workshop on Riparian Forest vegetated channels: hydraulic, morphological and ecological aspects, Trento, Italy, 20-22 February 2003.

Vermeulen T.J., (2003). Sensitivity analysis of fine sediment transport in the Humber Estuary. Masters, Delft University of Technology.

Warner, J. C., Sherwood, C. R., Signell, R. P., Harris, C. K., and Arango, H.G., (2008). Development of a three-dimensional, regional, coupled wave, current, and sediment $\square$ transport model, Comput. Geosci., 34(10), 1284-1306.

Warner, J.C., Armstrong, B., He, R., and Zambon, J.B., (2010). Development of a coupled ocean-atmosphere-wave-sediment transport (COAWST) modeling system. Ocean Model., 35 (3), pp. 230-244.

Wiberg, P. L., Carr, J. A., Safak, I., and Anutaliya, A., (2015). Quantifying the distribution and influence of non $\square$ uniform bed properties in shallow coastal bays. Limnology and Oceanography: Methods, 13(12), 746-762. https://doi.org/10.1002/lom3.10063

Zhang, X., Leonardi, N., Donatelli, C., and Fagherazzi, S. (2019). Fate of cohesive sediments in a marsh-dominated estuary. Advances in Water Resources, 125, 32-40. 